\title{
Wilsonian Ambitions for American Engagement in the First Gulf War
}

\section{Ashley Cox, SOAS University of London}

Abstract

American engagement with the world is one of the most important factors in international relations. One leading example is the Wilsonian School, which has a long tradition of influencing American foreign policy. With the 25th anniversary of Operation Desert Storm, this article will review the Wilsonian influences that led the United States to intervene in the First Gulf War.

Since the end of the Cold War, visions have differed dramatically in terms of how the United States should conduct foreign policy and engage with the rest of the world. These debates continue to be dominated by a clash between a Jeffersonian neo-isolationist call to withdraw from international conflicts and a more hawkish interventionist vision of American primacy in foreign affairs. The Wilsonian tradition has arguably received comparatively little discussion by scholars despite the important role it has played in the history of American foreign policy. As we mark the 25th anniversary of operation Desert Storm, this article argues that the Wilsonian framework is helpful in understanding why President Bush entered the First Gulf War of 1991. The article begins with a discussion of what constitutes the Wilsonian ideology in terms of its key principles and assumptions before presenting the utility of the Wilsonian viewpoint in explaining this conflict.

Introduction

The 2016 election in the United States showed two opposing vision of foreign policy and engage with the rest of the world. These debates were dominated by a clash between a Jeffersonian neoisolationist call to withdraw from the world or a more hawkish interventionist vision of American primacy. These are not the only foreign policy traditions in the history of the United States, and it is perhaps the Wilsonian tradition that has seen the least airing in recent discussion. Thus, this author believes it is a good time to revisit the role Wilsonianism has played in the history of foreign policy of the United States. As we mark the 25th anniversary of operation Desert Storm, this article will show that the Wilsonian framework plays a key role in understanding why President Bush entered the First Gulf War of 1991. Although we can see that Wilsonianism was not the only factor at work in President Bush's decision, we can see that it is an important and motivating factor often overlooked in the contemporary discourse on the conflict. This article begins with a discussion of what constitutes the Wilsonian ideology, its key principles and assumptions. This will by necessity be a truncated discussion focusing on the two key pillars of international law and democracy promotion. Finally, it will demonstrate the utility of the Wilsonian lens in explaining this conflict.

A Definition of Wilsonianism 
This is the version of the article accepted for publication in History Compass by Wiley. Published version available at: http://onlinelibrary.wiley.com/doi/10.1111/hic3.12365/abstract

Accepted version downloaded from SOAS Research Online: http://eprints.soas.ac.uk/24317/

What constitutes Wilsonianism is a contested subject amongst scholars of the history of foreign policy of the United States.1 In this section, we will discuss these concepts and produce a synthesised definition of Wilsonianism to aid in our understanding of the First Gulf War. Wilsonianism as an approach to foreign policy rests on two key pillars, the first is democracy promotion and the second collective security grounded in a rules-based international system. In this section, we will discuss each pillar and how they form the basis of the Wilsonian ideology.

The first of which is democracy promotion, that the United States has both an ideological commitment and a security interest in promoting democracy in other countries. In recent years, this concept has become associated with the neo-conservative groups with in US policy discourse. 2 While the neoconservatives have clearly been at the fore front of making the argument for democracy promotion since the First Gulf War. It is the Wilsonian School, this paper contends, that will demonstrate how to help us better understand a key part of the decision to liberate Kuwait in 1991. This article will use the definitions presented by Tony Smith and Walter Russell Mead to produce a synthesised definition of the term. According to Mead, Wilsonianism is grounded in the missionary tradition of the United States.3 By drawing on the precepts of democratic peace theory, 4 Wilsonianism as an ideology posits that an international system that consists purely of democracies will not resort to violence as democratic governments do not attack each other. This reflects the peaceful nature of democratic states and a domestic political culture of compromise to achieve political aims. As such, we do not need to view Wilsonianism as an idealistic philosophy. Smith argues that the United States sought to further its 'national security by encouraging likeminded democratic states to come into existence throughout the world.' 5 Wilsonianism also posits 'that the United States has the right and the duty to change the rest of the world's behaviour, and that the United States can and should concern itself not only with the way other countries conduct their international affairs, but with their domestic policies as well.' $6 \mathrm{It}$ is understanding this belief in the both the utility and the legitimacy of United States forging an international system that is line with its own preferences that will add to our understanding of George H.W. Bush's decision to liberate Kuwait.

The second key pillar is that of collective security and the importance of a rules-based international system. Wilsonian's believe that until the international system consists entirely of democratic states the conflict caused by anarchy within the international system is best addressed by a system that would deter aggression by presenting would be aggressors with an overwhelming international coalition. This will shift the cost benefit analysis of any potential aggression in favour of a diplomatic solution. It is on the issue of collective security that Wilsonian's part ways with their democracy promoting brethren in the neo-conservative camp. Although Wilsonians may see the United States as primus inter pares. They believe that there is a fundamental advantage in building a rules-based international system and vigorous enforcement of these rules through the use of international organisations. This is evidenced in Wilsonian support for the League of Nations and its successor the United Nations. Both of these organisations are premised on the fundamental illegitimacy of territorial expansion through military means. The United Nations had been created to prevent the mistakes of the interwar years and to meet any aggression with an internationally organised response.7 As the most powerful state in the international system, it would be the United States responsibility to enforce these rules and act as the final guarantor of collective security. These two 
This is the version of the article accepted for publication in History Compass by Wiley. Published version available at: http://onlinelibrary.wiley.com/doi/10.1111/hic3.12365/abstract

Accepted version downloaded from SOAS Research Online: http://eprints.soas.ac.uk/24317/

pillars present markedly different priorities than explanations that are grounded in strategic and economic factors that have traditionally been used to explain the First Gulf War. In the following sections, this paper will show that the Wilsonian framework adds to our understanding of this conflict.

Wilsonianism and the First Gulf War

The First Gulf War is a particularly apt example to investigate how Wilsonian preferences influence American decision-making as the conflict takes place at a time of change in the international system. The Cold War had made the functioning of collective security difficult. With its demise, there was renewed hope among Wilsonians that the Security Council would be able to cooperate and act to ensure international security. The first test of this new system was the Iraqi invasion of Kuwait. This conflict presented a clear case of an aggressor crossing an international boarder, a situation that collective security was supposed to prevent. It was clear that President Bush found this invasion objectionable, as he recalls 'at some point it came through to me that this was not a matter of shades of grey, or of trying to see the other side's point of view. It was good versus evil, right versus wrong.' 8 The Wilsonian School echoes in these words, as the need to right an obvious wrong are hallmarks of this school. The minutes of the National Security Council of 5 August 1990 show that both military and non-military options are discussed. President Bush says 'My sense is that Iraq does not believe we will act. Saddam is riding an emotional high. Maybe if he sees it is not business as usual he will change.' 9 This response is in line with the Wilsonian framework, not a rush to war but a clear understanding that if the international order is not restored then the United States must respond.

The second element the Wilsonian School adds to this conflict is an understanding of the importance that intervention in the Persian Gulf was driven by George H. W. Bush's belief that a new Americanled internationalism would replace the Cold War adversarial system. In the future, aggressive states would be met with collective action lead by the United States. The New World Order is a term that lacks clear definition, but it represents a policy of American-led internationalism based around the co-operation of nation states. This was an attempt to move to a more collective form of security:

In the minds of key leaders worldwide, collective security stood at the center of the new world order. In this sense, it was vital to prospects for creating a more stable, predictable, safe world.10

This is clearly a policy derived from the collective security pillar of the Wilsonian School. It is also clear that President Bush saw the United Nations and democratic norms as the foundation of this new order: 'The world can therefore seize this opportunity to fulfil the long-held promise of a new world order-where brutality will go unrewarded, and aggression will meet collective resistance.'11 This theme of America leading the world in collective action, with the United Nations as the instrument through which this is achieved, is the pinnacle of this pillar of the Wilsonian school. President Bush shows his support for this approach in many of the speeches and interviews that the president makes regarding this issue.12 In the same address, he articulates his view that: 
This is the version of the article accepted for publication in History Compass by Wiley. Published version available at: http://onlinelibrary.wiley.com/doi/10.1111/hic3.12365/abstract

Accepted version downloaded from SOAS Research Online: http://eprints.soas.ac.uk/24317/

Among the nations of the world, only the United States of America has both the moral standing and the means to back it up. We're the only nation on this Earth that could assemble the forces of peace. This is the burden of leadership and the strength that has made America the beacon of freedom in a searching world.13

This argument is supported by Engel, who argues that:

Bush believed it was American-led international resolve and America-led leadership of an international coalition of democracies that had secured the great victories of Bush's own youth and that had set the stage for the free world's triumph over communism. The grand challenges of his own post-Cold War world would, he believed, be best won in a similarly grand and international fashion.14

The decision to get a resolution explicitly authorizing the use of force, rather than use of the collective self-defence provision of the United Nations charter, lends further credence to the notion of this American-led internationalism.15 Smith argues that President Bush 'showed his respect for the importance of international institutions. He involved the Soviet Union, and so seemed to be paving the way for a later collective security agreement with Moscow.'16 This position is supported by John Ballard who argues that:

Scowcroft was concerned that the other policymakers within the NSC were not seeing the bigger picture he felt that this first major intervention of the post-Cold War world had enormous ramifications, and in their discussions the president agreed with him.17

Miller and Yetiv argue that the Gulf crisis itself was the catalyst for Bush's vision of a New World Order and that the situation clarified the need for American-led internationalism in a way that had not been clear before:

The end of the cold war and the Gulf crisis contributed fundamentally to the development of the concept of the new world order. The end of the cold war created conditions that made a new world order possible in theory.18

In their argument, the 'Gulf Crisis allowed the New World Order concept to be developed and executed. Indeed, prior to the crisis the notion of a new era was in the air, but it was ambiguous nascent and unproven.'19

The decline of the Soviet empire in Eastern Europe and the decline in the Soviet Union could have triggered a unilateral response to Saddam's invasion. It was George H. W. Bush's concept of an international response that moulded the attempts to generate a collective international effort to resolve the crisis. The Wilsonian framework furthers our understanding of why this is an important shift. As the domestic nature of the Soviet state changed so did the Wilsonian's view of how disruptive a state it would be to international peace. Those that had supported the democracy promotion pillar of the Wilsonian school had long argued that it was non-democratic states who 
This is the version of the article accepted for publication in History Compass by Wiley. Published version available at: http://onlinelibrary.wiley.com/doi/10.1111/hic3.12365/abstract

Accepted version downloaded from SOAS Research Online: http://eprints.soas.ac.uk/24317/

were the fundamental cause of conflict within the international system. The end of the Cold War and Soviet reforms seemed to validate these assumptions. At the Houston economic summit, the G7 declaration announced:

We welcome the intention of the Soviet Union to move toward a democratic political system, as well as Soviet attempts to reform their economy along market principles. We commit ourselves to working with the Soviet Union to assist its efforts to create an open society, a pluralistic democracy, and a market-oriented economy. Such changes will enable the Soviet Union to fulfill its responsibilities in the community of nations founded on these principles. We are heartened by indications that a constructive dialogue is underway between the Soviet government and the Baltic states, and we urge all sides to continue this dialogue in a democratic spirit.20

With the Soviet Union no longer acting as an obstruction in the United Nations, Wilsonians could further the second pillar of the school and pursue a collective security approach. If we return to the concept of the New World Order, and its role in President Bush's response to the crisis as a collective security response, there existed a need to ensure the Soviets were comfortable with the function of the system as this would be an important part in getting the system to work. President Bush says in conversation with President Gorbachev in June of 1991:

We seek a democratic, market-oriented Soviet Union, integrated into the world economy, having found a resolution of the problems between the center and the republics. The latter is essential for capital flows. We also seek cooperation on all global issues. I know your historical relations with Iraq and appreciate the bold decision you made on the Gulf.21

It was important to the Bush administration that the response to the Gulf crisis could be used as a template for how an international crisis should be resolved. To this end, the Bush Administration halted ground operations, whilst significant assets of the Iraqi military were still intact. The United States had followed its mandate from the United Nations and not made the mistakes that it had during the Korean War of extending the mission to removing the aggressor from power. If the 'United States wanted the Gulf crisis to set a precedent for collective action, it made sense to stay within the parameters of that mandate.' 22 It was this desire to make internationalism under American leadership work, which was part of the decision not to try to remove Saddam, and as a result as Mead argues 'Wilsonians could call it a war for international law, with the U.N. Security Council acting as Wilsonians has always hoped it would.'23 Bush makes it clear when he announces the suspension of hostilities 'No one country can claim this victory as its own. It was not only a victory for Kuwait but a victory for all the coalition partners. This is a victory for the United Nations, for all mankind, for the rule of law, and for what is right.'24

President Bush reiterates this position in a speech to the United Nations General assembly:

This is a new and different world. Not since 1945 have we seen the real possibility of using the United Nations as it was designed: as a center for international collective security. The changes in the Soviet Union have been critical to the emergence of a stronger United Nations. The U.S.-Soviet 
This is the version of the article accepted for publication in History Compass by Wiley. Published version available at: http://onlinelibrary.wiley.com/doi/10.1111/hic3.12365/abstract

Accepted version downloaded from SOAS Research Online: http://eprints.soas.ac.uk/24317/

relationship is finally beyond containment and confrontation, and now we seek to fulfil the promise of mutually shared understanding. The long twilight struggle that for 45 years has divided Europe, our two nations, and much of the world has come to an end. Much has changed over the last 2 years. The Soviet Union has taken many dramatic and important steps to participate fully in the community of nations. And when the Soviet Union agreed with so many of us here in the United Nations to condemn the aggression of Iraq, there could be no doubt - no doubt then - that we had, indeed, put four decades of history behind us. We are hopeful that the machinery of the United Nations will no longer be frozen by the divisions that plagued us during the cold war, that at last - long last - we can build new bridges and tear down old walls, that at long last we will be able to build a new world based on an event for which we have all hoped: an end to the cold war. 25

These comments above demonstrate both of the key pillars of the Wilsonian School. In this speech, it is President Bush's assertion that the change in the relationship between the superpowers is due to its change toward a more democratic form of government, a clearly Wilsonian explanation for the end to the confrontation. This speech also demonstrates the role of the Wilsonian approach in the President's resolution of the Iraqi invasion of Kuwait and his support for a collective security, through the United Nations. For this Wilsonian vision to work successfully, Bush would need to ensure that the great powers of the post-Cold War world would co-operate. This was particularly important to the Permanent Five members of the United Nations Security Council. If the United Nations was to be the body to co-ordinate this post-Cold War it could not suffer from the deadlock it had experienced during the Cold War period. Thus, through the Gulf Crisis, we see the continual consultations with the Soviet Union despite its weakened state. It is further testament to George H.W Bush's vision that the post-Cold War period would be one of consensus finding. If the president came out strongly against the invasion and the United Nations demanded Saddam withdraw his forces and subsequently the invasion became a fait accompli then it would be proven that the United Nation was no more capable of acting in the post-Cold War world than it had been in the Cold War. The Wilsonian framework will show why this contributed to America's decision to intervene. Understanding that the core of Bush's foreign policy and vision for the post-Cold War world was internationalism under American leadership is a critical part of understanding the American response to the Iraqi invasion of Kuwait. It is the Wilsonian framework that adds to the understanding of why this is important.

The Post-Cold war era and the New World Order

The focus of the Bush administration's response was on restoring Kuwait to the status quo antebellum, defeating Iraqi aggression and trying to limit the disruption to the United States economy. This is not to argue that the president was not interested in democratic expansion, but the New World Order was only one of the approaches taken by the United States to post-Cold War conflicts. It is important to remember that the First Gulf War took place in a period of transition from a multipolar order to the unipolar of the post-Cold War period. The Cold War was over, and the Soviet Union was drawing its last breaths. Engel argues that the end of the Cold War was 'a validation of American values and policies.'26 President Bush was not alone in his assumption that the tide of history was flowing towards democracy- many scholars, such as Francis Fukuyama, heralded the end of communism as a new phase in international relations where a democratic peace would replace the competitive international system, an argument the Wilsonian School had long made.27 This meant that there was little need for active regime change in non-democratic countries. Simply by 
This is the version of the article accepted for publication in History Compass by Wiley. Published version available at: http://onlinelibrary.wiley.com/doi/10.1111/hic3.12365/abstract

Accepted version downloaded from SOAS Research Online: http://eprints.soas.ac.uk/24317/

waiting these regimes out the U.S. would prevail much as it had done in the Cold War. Only if a nation upset the status quo, such as Iraq had, would America need to act. President Bush argued that:

I did not think we should impose democracy on Kuwaitis-rather; it was something that had to grow from within. We could not allow a dictator to be the one to alter their domestic political structure. Above all, we could not give Saddam any measure of political gain from the invasion. Had we insisted on imposing democracy as part of the restoration of sovereignty, Saddam could portray himself as a catalyst for Kuwaiti political reform.28

Tony Smith agrees with this assessment, as he argues:

Democracy was not the issue; neither in Iraq nor in Kuwait could there be much hope of fostering so Western a style of government. Nevertheless, here was a challenge to regional stability in an area of special interest to the United States, so that in acting decisively, Bush might give still more shape to what he now called a "new world order" to be crafted by American leadership.29

Despite the long-term failure of the New World Order, which goes beyond the scope of this article, the administration's actions in Kuwait show an attempt to establish this order, through an insistence on the respect for national sovereignty as the basis of this order. This brought him in to conflict with the French Premier Mitterrand who said 'I would not risk the death of one single French soldier if it was exclusively in order to restore an absolutist system.'30

It may seem counter intuitive to suggest that the Wilsonian School would not wish to install democracy in the nation of Kuwait.31 This conflict demonstrates the ascendency of the collective security pillar in this conflict, ensuring that the United Nations would be able to act as the organisation to facilitate this collective security. As such it was important in gaining the support of regional powers for the action to return the Amir to power. Although the democracy promotion pillar of Wilsonianism appears to have taken a back seat in this conflict, we can also view this in the light of the successful approach to the Cold War. As we have discussed above, the events in Eastern Europe had presented a vindication of the Wilsonian School's approach with evidence of the inevitability of the victory of democratic government of communism. 32 The President in a joint press conference with British Prime Minister John Major comments:

What's different is we are not facing one aggressive international Communist force; that's what's entirely different. Democracy is on the move in these various countries you talk about. I don't know that any one of them wants to now turn its back on democracy, and some of those who have not been particularly democratic are saying they are. 33

Supporters of Wilsonian ideals had waited over forty years for democracy to spread to Eastern Europe, it could bide its time for it to reach the Middle East. The Wilsonian approach is a patient one. 
This is the version of the article accepted for publication in History Compass by Wiley. Published version available at: http://onlinelibrary.wiley.com/doi/10.1111/hic3.12365/abstract

Accepted version downloaded from SOAS Research Online: http://eprints.soas.ac.uk/24317/

This willingness to allow democracy to spread at its own pace also shows a distinct difference from the neoconservative approach. Those that support the Wilsonian approach are far more sceptical over the efficacy of the concept of imposing democracy at the point of a bayonet.34 The above section shows that the Wilsonian School had a significant impact on the United States actions, and that the strategic and economic motivations do not, on their own, explain this conflict Wilsonianism is a powerful influence on the president's decision, and we must consider this influence to fully understand this conflict.

Conclusion

In conclusion, we can see that there is significant evidence that George H.W. Bush was motivated by a desire to create a rules-based international system, where the United States would lead the world in collective action against aggressors. In this New World Order, the United Nations would also take a central role in providing a collective security function. This was in line with the principles of the Wilsonian framework that had always supported the use of an international organisation to keep the peace.

The Bush administration had hoped that in light of the Cold War ending the democratic norms of the West would become global democratic norms. This conflict can be seen as a way to show that those norms that included resolving your differences with other states through peaceful means and not through conflict would be enforced in the post-Cold War world.

Many have argued that this intended New World Order was nothing more than a cover for post-Cold War American hegemony and that if a New World Order was important then the subsequent Bush years would have seen a more concerted effort to establish this order. However, the events of this period show great restraint by the United States on how it used its power, especially with the final collapse of the Soviet Union in 1991, as well as the large humanitarian effort in Somalia in 1992.

This is not to dismiss the clear threat that Iraq presented to the region, which of course played a significant part in shaping the American response to the crisis. During the crisis, the president went to great lengths to consult other world leaders and to attempt to find a non-military solution to Iraqi aggression. But at no point did the president consider that there would be any solution that left Iraq in control of Kuwait. By revisiting these events using the Wilsonian framework, we can gain understanding of why the threat was resolved the way it was. Finally, it was a great challenge for President Bush to keep the coalition together, with various internal tensions threatening to tear it apart. Thus, if the United States had not responded as it did with the genuine threat of force and acted when it did to forcibly remove Iraqi forces from Kuwait, then the consensus may have collapsed at which point the whole sanctions regime would have fallen apart and Iraq could reap the rewards of aggression. It is the larger Wilsonian framework that helps us understand why the president was motivated to act.

Notes 
This is the version of the article accepted for publication in History Compass by Wiley. Published version available at: http://onlinelibrary.wiley.com/doi/10.1111/hic3.12365/abstract

Accepted version downloaded from SOAS Research Online: http://eprints.soas.ac.uk/24317/

1

For these competing definitions see: Ambrosius, Lloyd E. Wilsonianism: Woodrow Wilson and His Legacy in American Foreign Relations (New York: Palgrave Macmillan, 2002), Smith, Tony. America's Mission: The United States and the Worldwide Struggle for Democracy in the Twentieth Century (Princeton: Princeton University Press, 1994), Mead, Walter Russell. Special Providence: American Foreign Policy and How it Changed the World, (New York: Random House, 2001), Ninkovich, Frank. The Wilsonian Century: U.S. Foreign Policy Since 1900 (Chicago: University of Chicago press, 1999)

2

Neo conservative is a broad term used to describe US Conservative groups that believe that the United States should use its power and military might to expand democracy. For further reading on this group and its beliefs, see Ryan, Neo Conservatism in the New American Century, Steinfels, The Neo Conservatives: the origins of a movement, Simon and Schuster and Kristol, The Neo-

Conservative Persuasion.

3

Mead, Special Providence, location 2604.

4

Harrison, "The democratic peace research program and system-level analysis", pp. 155-165, Macmillan, "Liberalism and the Democratic Peace", pp. 179-200 and Brown et al (eds), Debating the Democratic Peace.

5

Smith, America's Mission p8

6

Mead, Special Providence, location 2612

7

UN Charter, Chapter One Article One, http://www.un.org/en/sections/uncharter/preamble/index.html 
This is the version of the article accepted for publication in History Compass by Wiley. Published version available at: http://onlinelibrary.wiley.com/doi/10.1111/hic3.12365/abstract

Accepted version downloaded from SOAS Research Online: http://eprints.soas.ac.uk/24317/

8

Bush and Scowcroft, A World Transformed p. 375

9

Alfonsi, Circle in the Sand p. 76

10

Yetiv, Persian Gulf Crisis, p. 94

11

Bush, 'State of the Union Address (January 29,1991)', http://millercenter.org/president/speeches/detail/3429.

12

Bush, 'Presidential Speech Archive', http://millercenter.org/president/speeches\#bush

13

Bush, State of the Union Address (January 29, 1991)

14

Engel, 'A Better World’ p. 11

15

Greenwood, 'New World Order or Old? The Invasion of Kuwait and the Rule of Law' pp. 153-178

16

Smith, America's Mission p. 318

17

Ballard, From Storm to Freedom p. 3 
This is the version of the article accepted for publication in History Compass by Wiley. Published version available at: http://onlinelibrary.wiley.com/doi/10.1111/hic3.12365/abstract

Accepted version downloaded from SOAS Research Online: http://eprints.soas.ac.uk/24317/

18

Miller and Yetiv, 'The New World Order in Theory and Practice' p. 57

19

Miller and Yetiv, 'The New World Order in Theory and Practice' p. 57

20

Office of the Press Secretary, 'Houston Economic Summit Political Declaration: Securing Democracy 1990-07-10', http://bushlibrary.tamu.edu/research/public_papers.php?id=2063

21

Department of State, 'Memorandum of Conversation, Mikael Gorbachev July 171991 ' Bush Presidential Library and Museum, http://bushlibrary.tamu.edu/research/pdfs/memcons_telcons/1991-06-17-Gorbachev.pdfhttp://bushlibrary.tamu.edu/research/pdfs/memcons_telcons/1991-06-21-Gorbachev.pdf

22

Miller and Yetiv, 'The New World Order in Theory and Practice' p. 64

23

Mead, Special Providence: p. 269

24

Bush, 'Address to the Nation on the Suspension of Allied Offensive Combat Operations in the Persian Gulf 1991-02-27' http://bushlibrary.tamu.edu/research/public_papers.php?id=2746

25

Bush, 'Address Before the 45th Session of the United Nations General Assembly in New York, New York 1990-10-01' http://bushlibrary.tamu.edu/research/public_papers.php?id=2280 
This is the version of the article accepted for publication in History Compass by Wiley. Published version available at: http://onlinelibrary.wiley.com/doi/10.1111/hic3.12365/abstract

Accepted version downloaded from SOAS Research Online: http://eprints.soas.ac.uk/24317/

26

Engel, 'A Better World' p. 10

27

Fukuyama, The End of History and the Last Man

28

Bush and Scowcroft, A World Transformed, p. 376

29

Smith, America's Mission, p. 314

30

Bush and Scowcroft, A World Transformed p. 376

31

For a discussion of how different regimes come to democracy see: Kirkpatrick, Dictatorships and Double Standards.

32

Stokes, The Walls Came Tumbling Down: The Collapse of Communism in Eastern Europe and Rady, Causes and Consequences of the Collapse of Communism in Eastern Europe.

33

Bush, 'The President's News Conference with Prime Minister John Major of the United Kingdom at Camp David', http://bushlibrary.tamu.edu/research/public_papers.php?id=4401

34

For a discussion of the Immediate Post-Cold War World see Cohen, Warren. America's Failing Empire (Malden: Blackwell Publishing,2005) Chapter Two or Mearsheimer, John. Tragedy of Great Power Politics, (New York: Norton, 2001) 